\title{
UCRL-TR-224286
}

LAW RENCE LIVERMORE N A TIO N A L LABORATORY

\section{The Computation Directorate at Lawrence Livermore National Laboratory}

L. Cook

September 8, 2006 
This document was prepared as an account of work sponsored by an agency of the United States Government. Neither the United States Government nor the University of California nor any of their employees, makes any warranty, express or implied, or assumes any legal liability or responsibility for the accuracy, completeness, or usefulness of any information, apparatus, product, or process disclosed, or represents that its use would not infringe privately owned rights. Reference herein to any specific commercial product, process, or service by trade name, trademark, manufacturer, or otherwise, does not necessarily constitute or imply its endorsement, recommendation, or favoring by the United States Government or the University of California. The views and opinions of authors expressed herein do not necessarily state or reflect those of the United States Government or the University of California, and shall not be used for advertising or product endorsement purposes.

This work was performed under the auspices of the U.S. Department of Energy by University of California, Lawrence Livermore National Laboratory under Contract W-7405-Eng-48. 


\section{The Computation Directorate At Lawrence Livermore National Laboratory}

May 2006

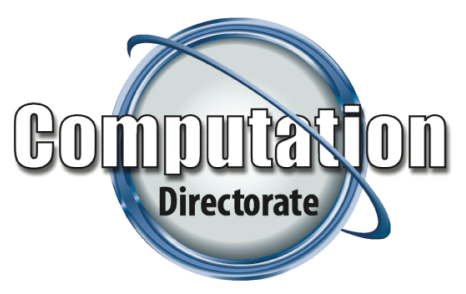

Computation Directorate

Lawrence Livermore National Laboratory 


\section{Outline}

- Overview of the Laboratory

- Overview of the Computation Directorate

- Facilities

- Livermore Computer Center

- LLNL and Computation Support for Important National Missions 


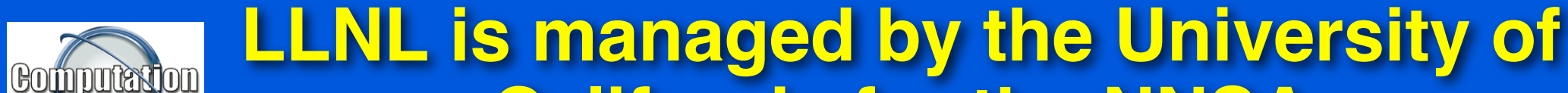 California for the NNSA}

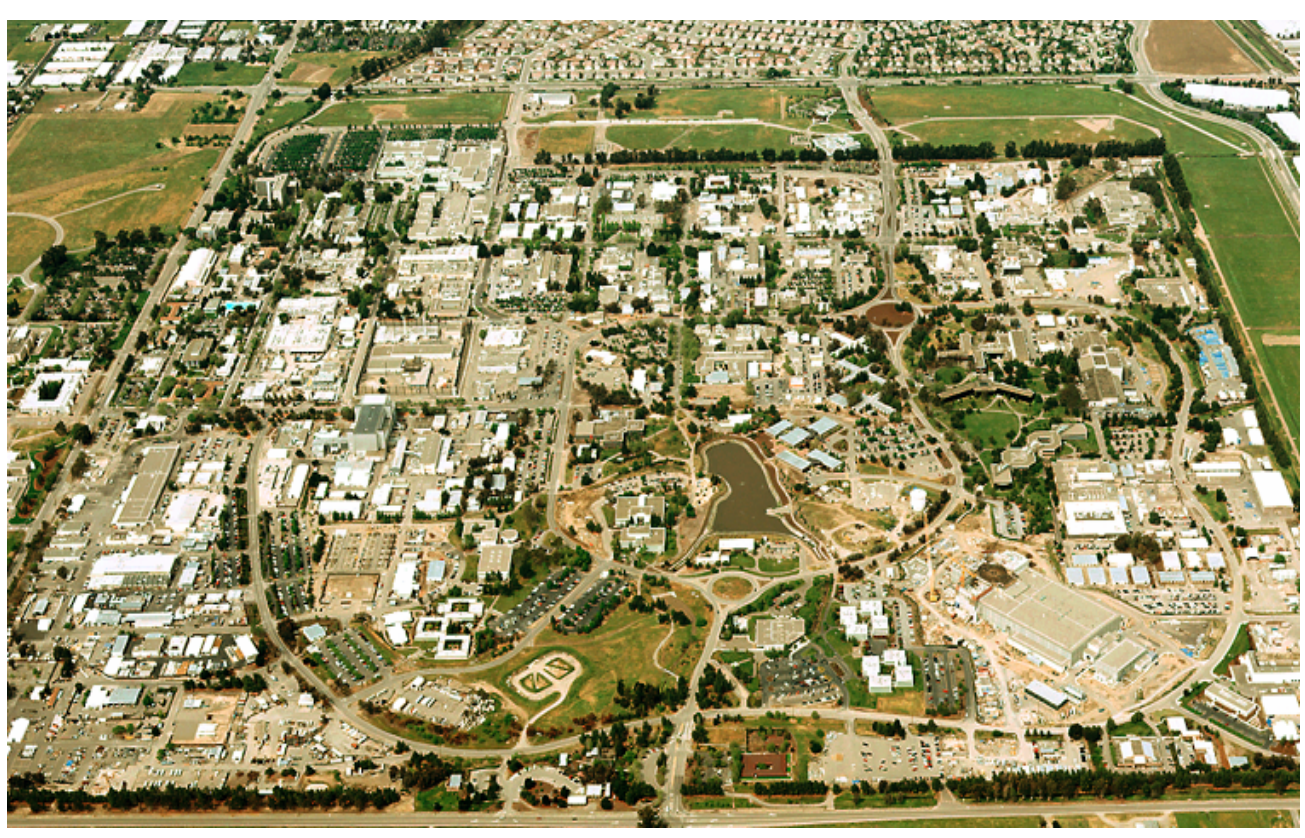

Our Mission: National Security in a Global Context
- Multi-program

- Multi-disciplinary

- "Big Science"

- \$1.6B annual budget

- 8300 employees

- 1 square-mile main site

- Experimental test site

- National Security

- Homeland Security

- Energy \& Environment

- Applied Science 


\section{Computation Directorate Vision and Mission}

\section{Vision}

Computation aspires to be the preeminent high performance computing and computer science organization in order to enable scientific discovery and

Laboratory missions.

\section{Mission}

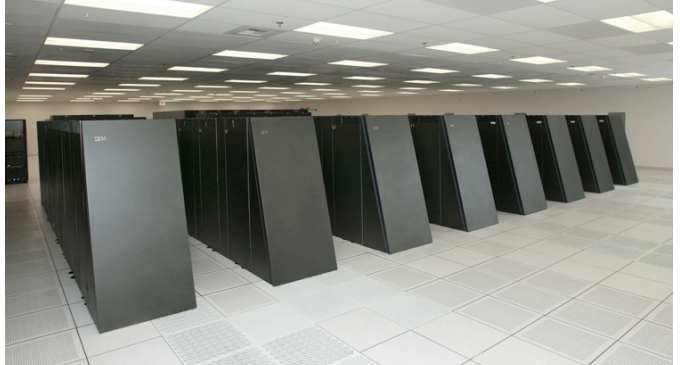

Computation assures Laboratory mission and program goals are attained by delivering outstanding computer science expertise, world-class high performance computing capabilities, and creative technology and software solutions. 


\section{Work in Computation}

- The Computation Directorate has four major areas of work:

- Programmatic Support:

- Programs are areas which receive funding to develop solutions to problems or advance basic science in their areas.

- Ex: Stockpile Stewardship, Homeland Security and the Human Genome project

- Computer scientists are "matrixed" to these programs to provide computer science support

- Livermore Computer Center (LCC):

- Development, support and advanced planning for the large, massively parallel computers, networks and storage facilities used throughout the laboratory

- Research:

- Computer scientists research advanced solutions for programmatic work and for external contracts and research new HPC hardware solutions

- Infrastructure:

- Support for thousands of desktop computers and numerous LANs, labwide unclassified networks, computer security, computer-use policy. 


\section{LLNL Computer Facilities and Infrastructure}




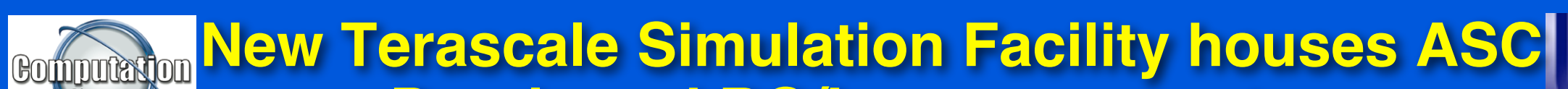
Purple and BG/L supercomputers

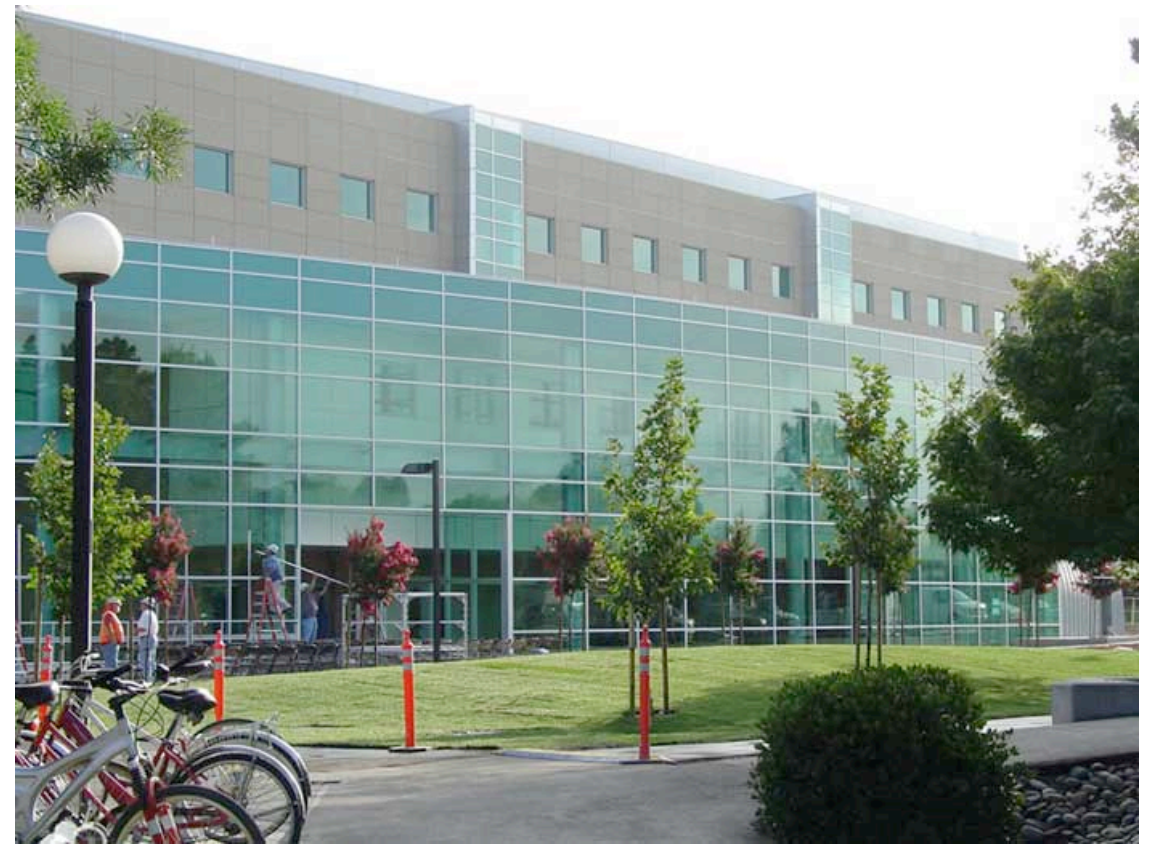

LLNL now has the most capable computing infrastructure in DOE
- State-of-the-art facility in the center of the Lab

- Two unobstructed computer floors totaling $>1$ acre (almost a football field of computer space!)

- Total power 12MW to power and cool computers (up to 15MW)

- 280 offices, meeting rooms, visualization theaters, operations support, tape vault, labs 


\section{LLNL Exploration in petascale computing}

Vendor-integrated MPP production stability 100TF ASC Purple

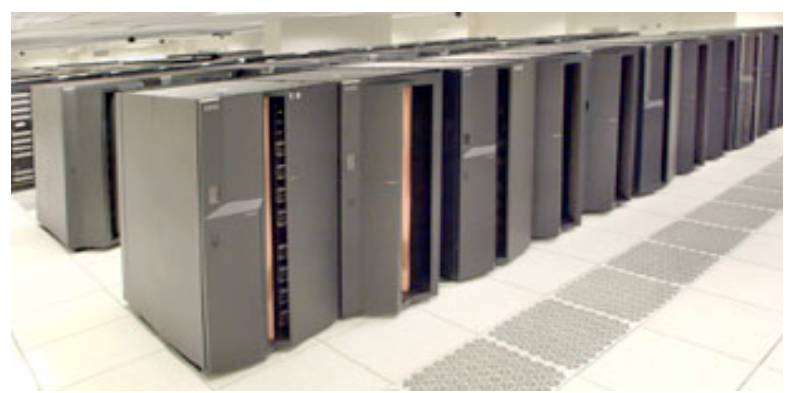

1,536 nodes 12,288 Power5 processors 50 TB memory AIX software
Linux clusters cost-effective science 23TF Thunder Linux cluster

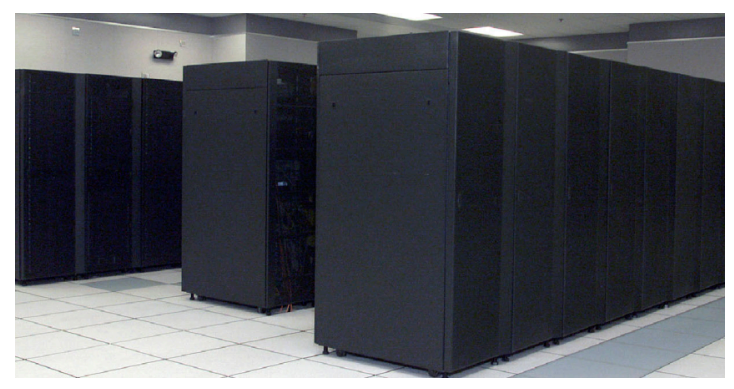

1,024 nodes 4,096 processors 16 TB memory Linux software
Novel architectures leading edge 360TF BlueGene/L

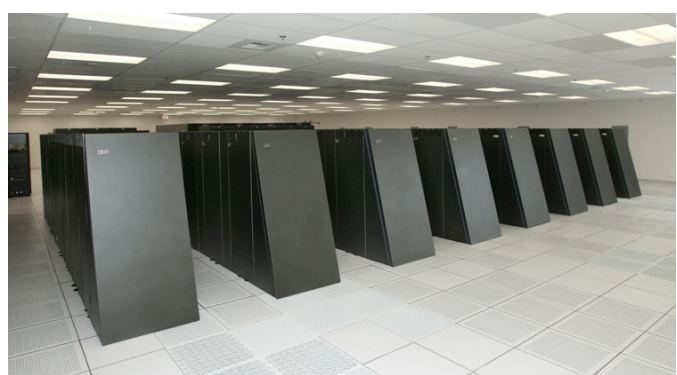

65,536 nodes 131,072 processors 32 TB memory 64 cabinets $1.5 \mathrm{MW}$

2500 square feet

BlueGene/L is the world's fastest supercomputer at 360TF and Purple is \#3 on the Top500 list of the world's fastest supercomputers!! 


\section{Big Computers - Powerful Networks}

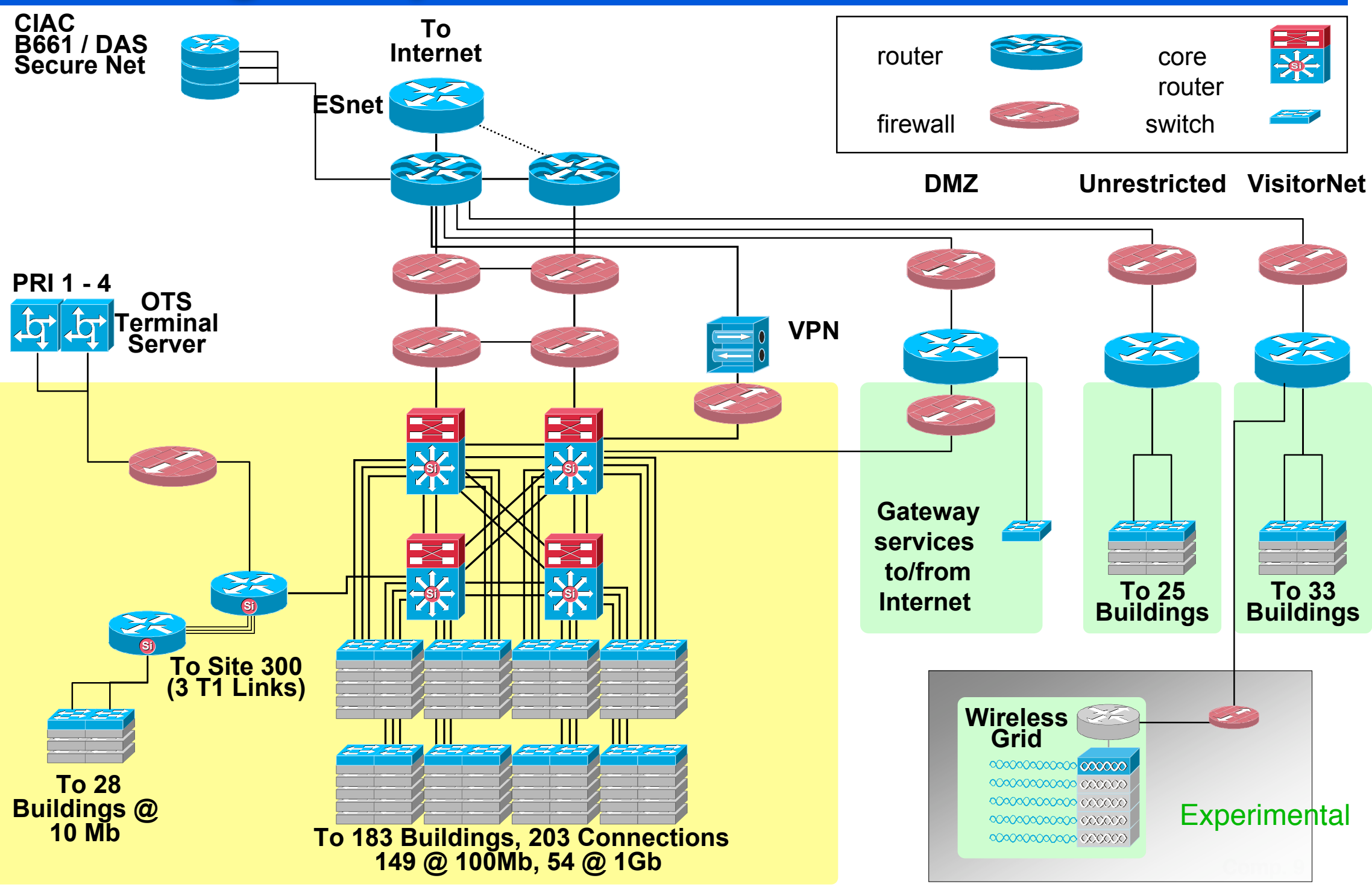




\section{Central Computer Services / Support}

- Customer Support, Hotline, Technical Consulting, Account Management

- Online Documentation, HPC Training \& Education, Customer Outreach

- Software and tools development for High Performance Computing (HPC) User support:

- Compilers

- Memory tools

- Debuggers

- Performance analysis tools

- Software evaluation

- In-depth consulting

- Tools development

- Vendor collaborations

- And more...

- Development and support of tools for managing, visualizing and presenting scientific data.

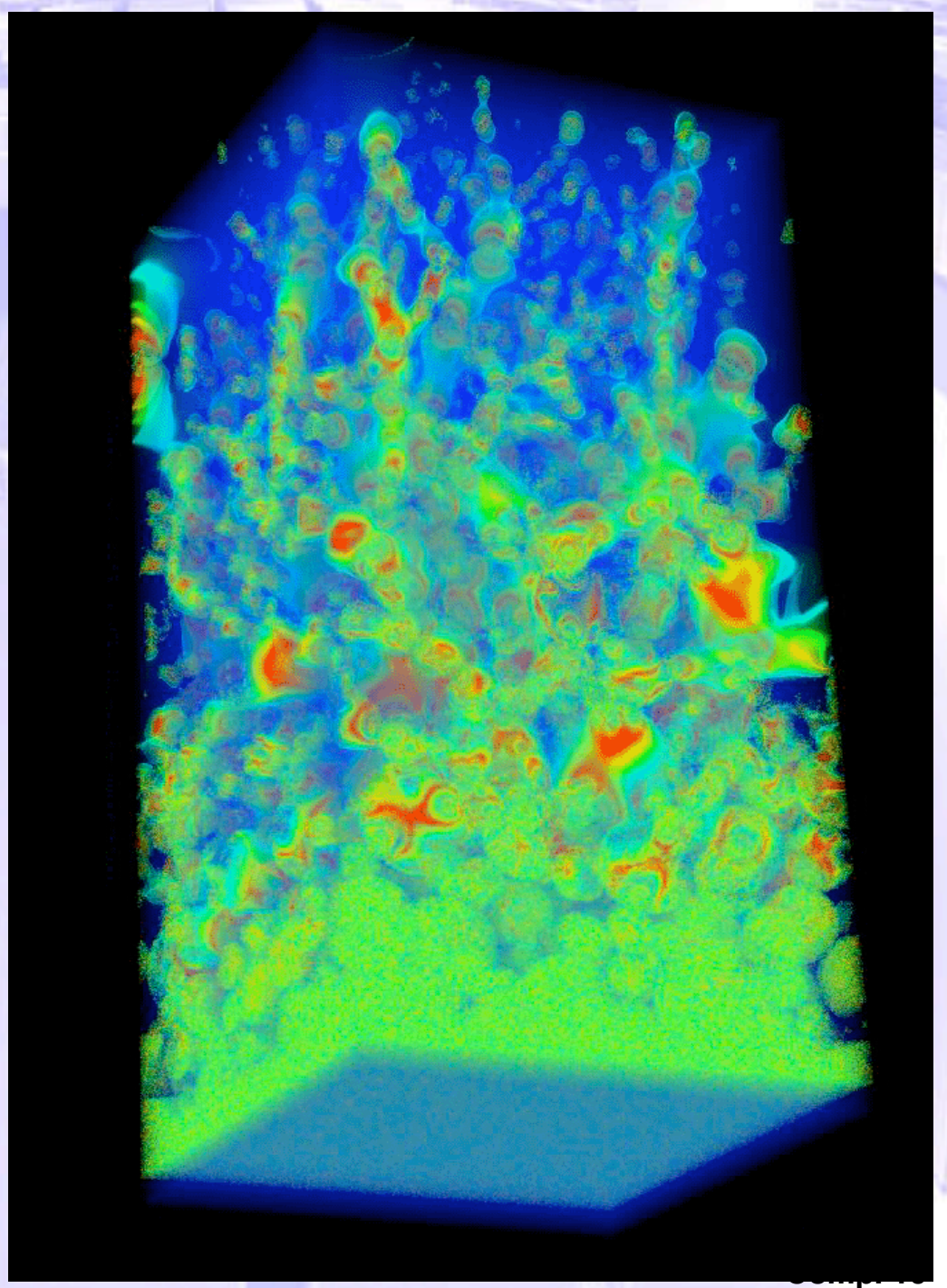




\section{Central Computer Services / Support}

- Network Services

- Email

- Anti-Spam

- Anti-Virus for email

- Mailing lists (majordomo)

- Pop Servers

- Calendaring (Meeting Maker)

- System Support Services

- Active Directory

- Imaging

- Software Distribution

- Configuration inventory

- OS Patch Management

- Desktop Anti-virus

- Computation Training Center
- 4Help Central help desk

- Desktop application support

- Network, desktop and computer security services support

- Remedy trouble ticket system

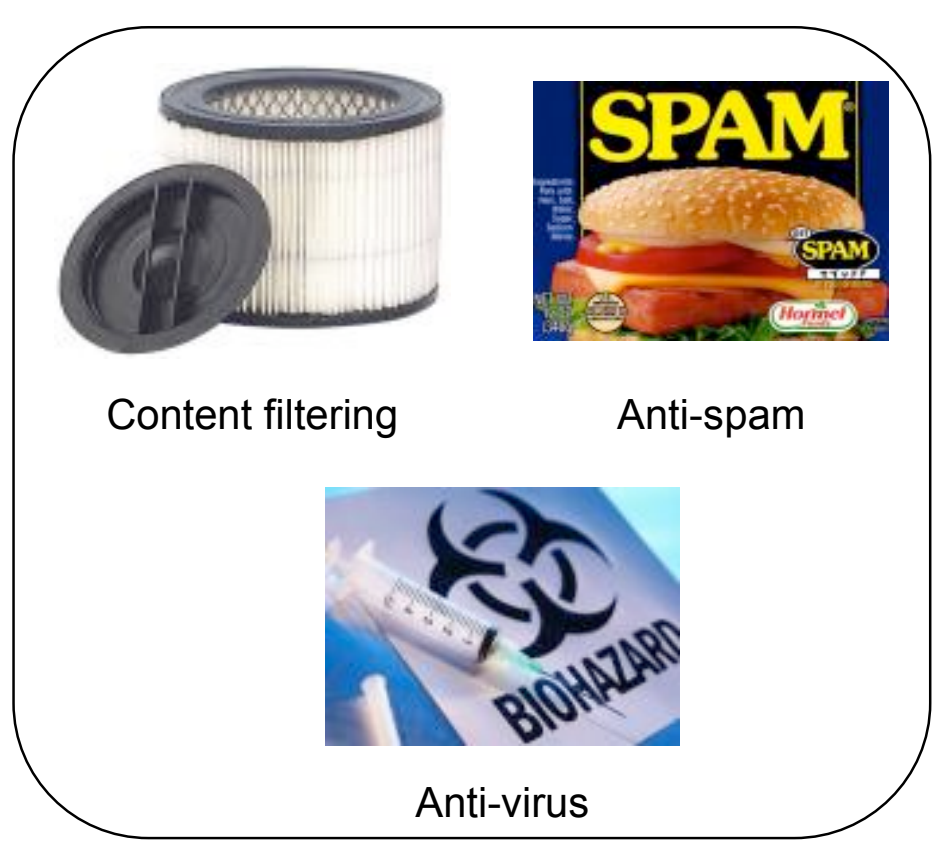

Comp. 11 


\section{LAN, Network and Desktop Support}

- A large staff of System Administrators provides IT Support for LLNL Directorates

- Hardware Support

- OS Support

- Software installation and troubleshooting

- Network Support

- Computer Security

- IT Project Management
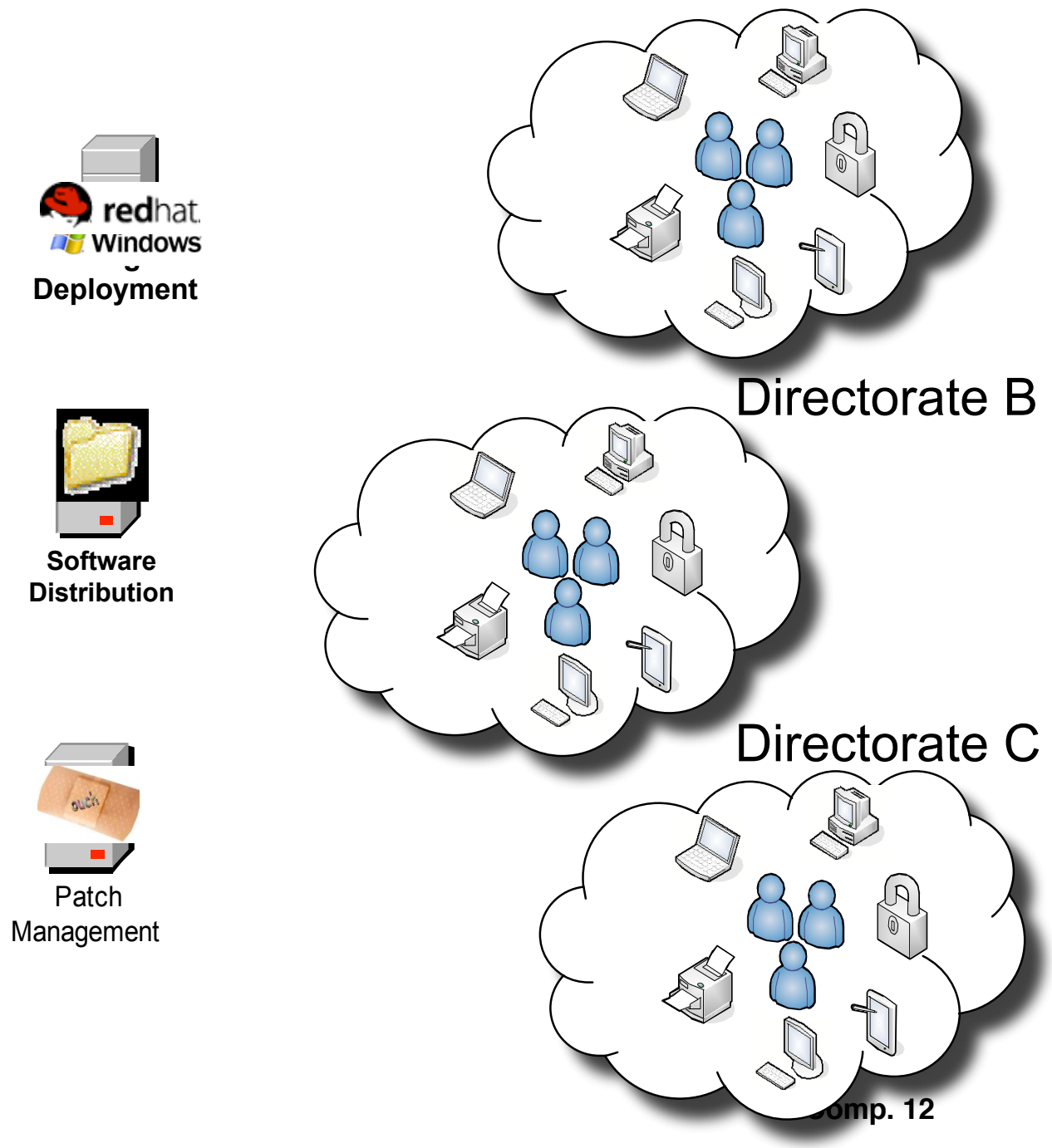


\section{Overview of LLNL's Programs and Computer Science Support for these Programs}




\section{A Code Team at LLNL}

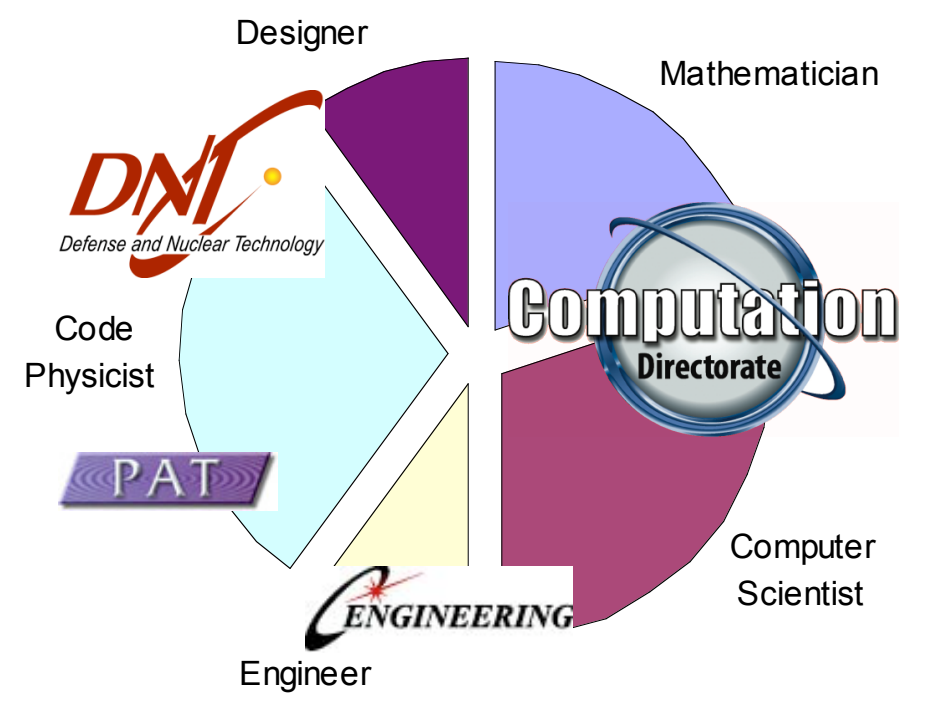

A typical project or code team draws expertise from several disciplines. A team developing a physics simulation code would include physicists, computer scientists, mechanical engineers, mathematicians and possibly a chemist. 


\section{Nonproliferation / Homeland Security}

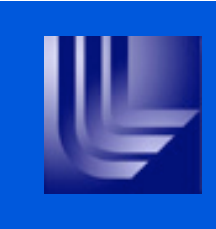

LLNL is a premier developer of systems solutions to preclude the proliferation, acquisition, or use of weapons of mass destruction.

This includes work in terrorism prevention, proliferation detection, incident response, international assessment of WMD capabilities.

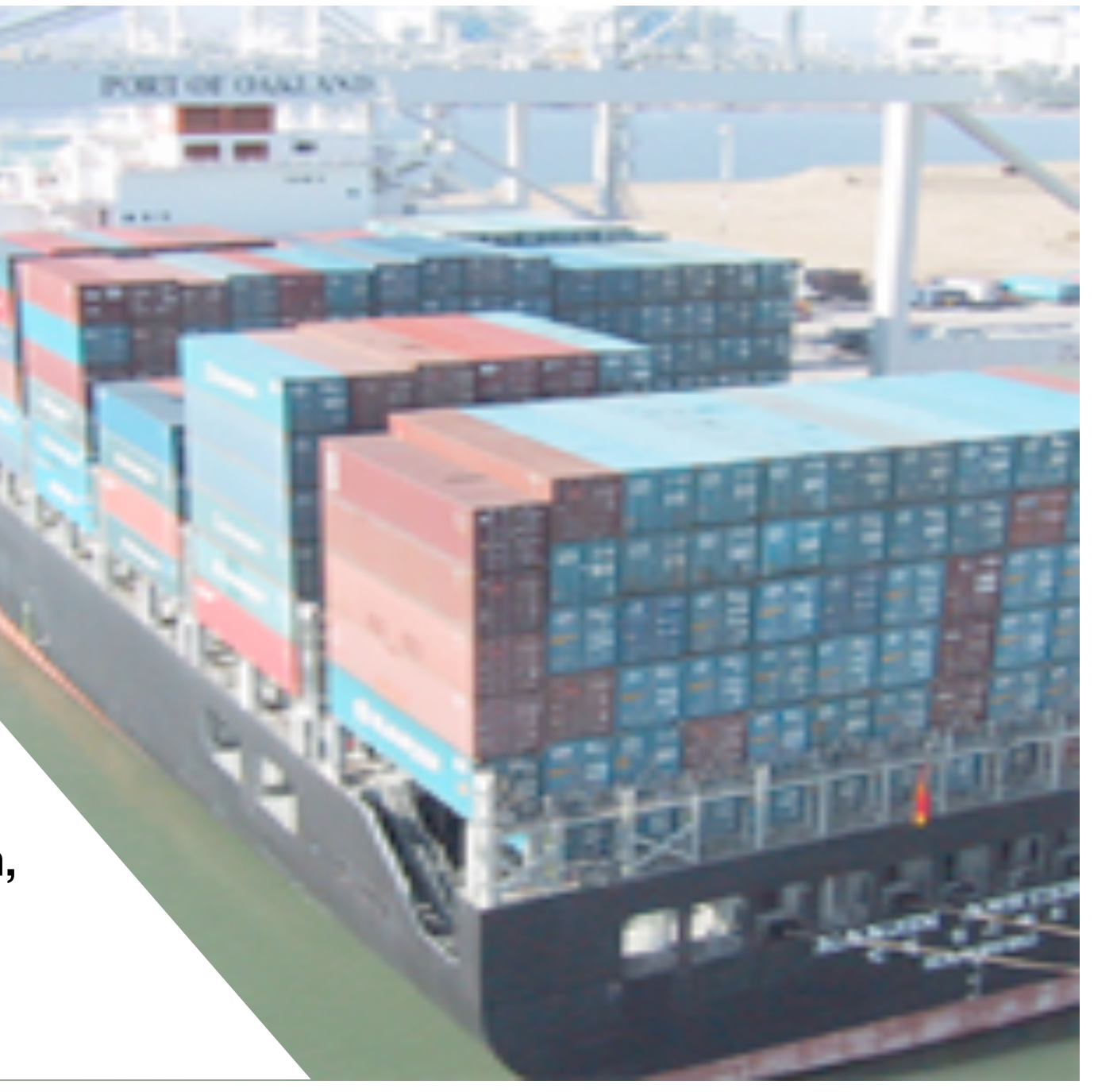




\section{Nonproliferation / Homeland Security}

\section{Text analysis}

Computer scientists develop conflict simulation codes, map and analyze networks for vulnerabilities, develop graph search tools, and develop text analysis and data fusion technology.

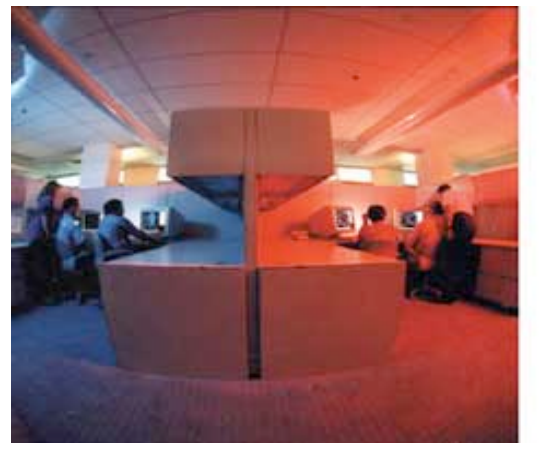

Joint Conflict \& Tactical Simulation

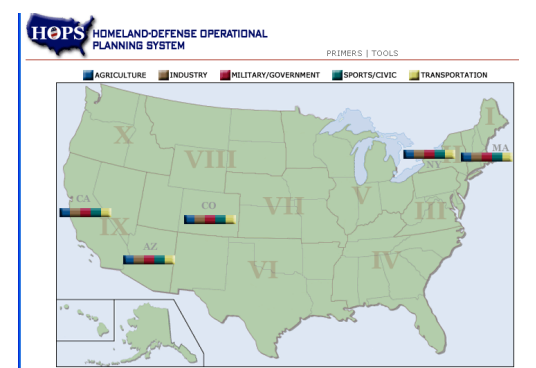

Homeland Defense Operational Planning System (HOPS)

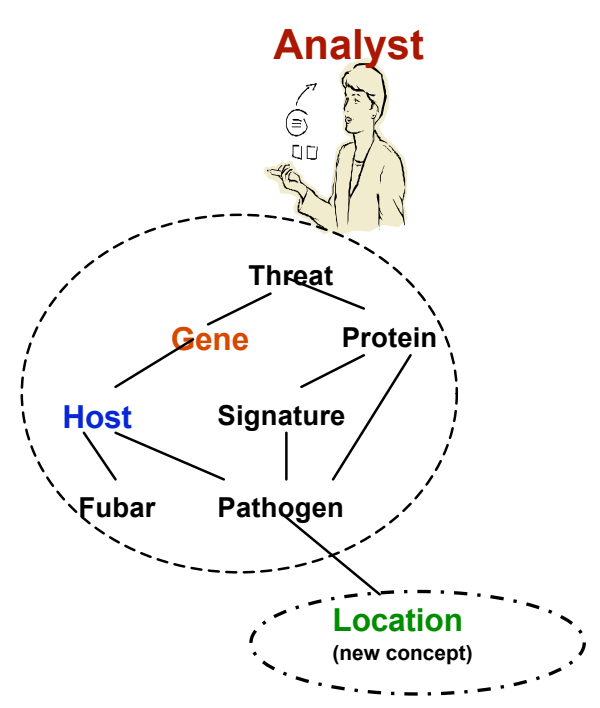

ProMed Mail

Entity and event extraction

Classification and clustering 

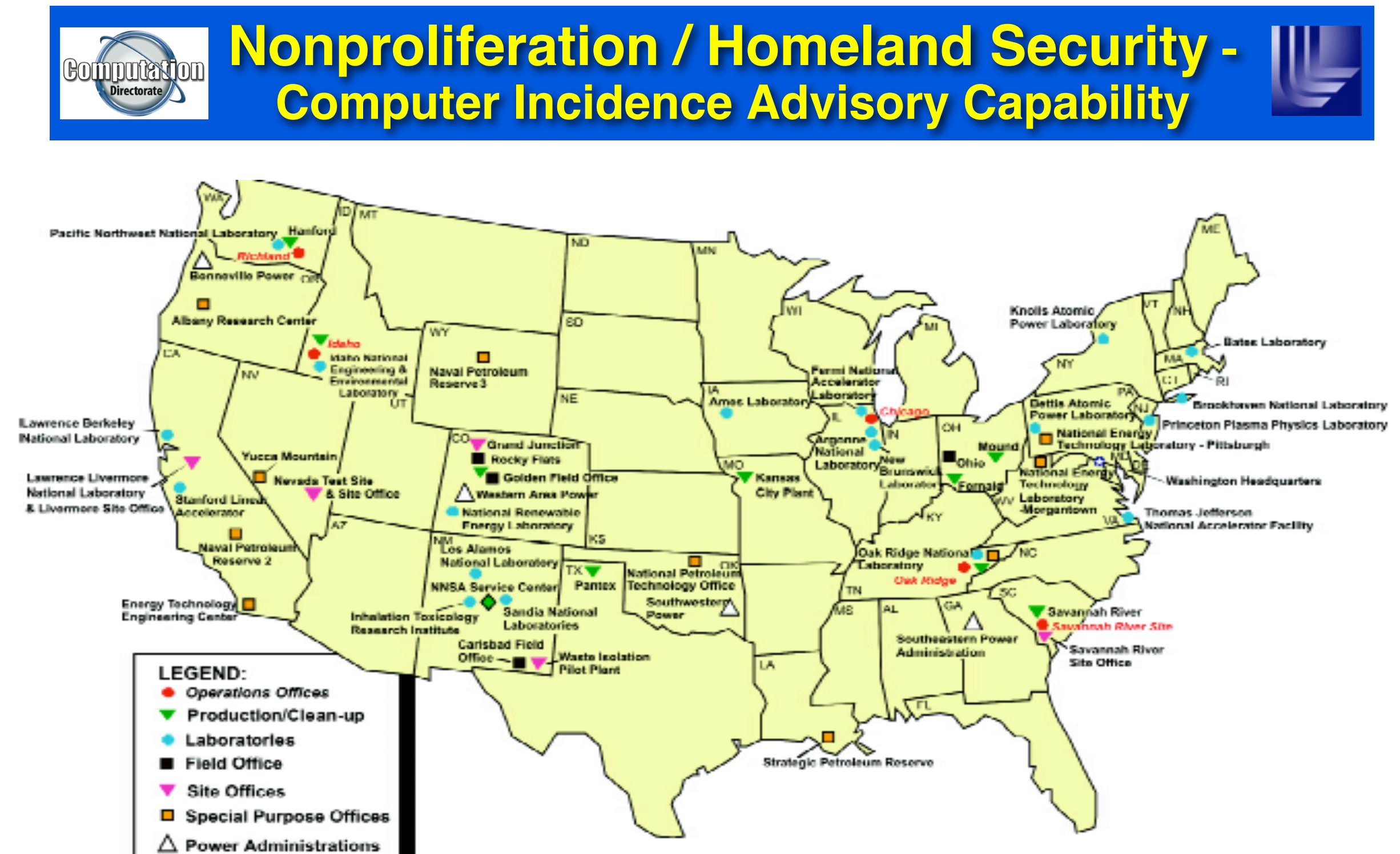

NnSA Service Center

CIAC provides cyber security services to

Washington D.C. 95 DOE and NNSA sites and field offices 


\section{Biosciences}

Bioscience research at LLNL is a program in molecular biology, genetics, genomics, computational biology, and biotechnology. These efforts are in the service of three main areas of societal need: human health, defense biology, and environmental health.

Computer Scientists develop genomic databases, web tools to access this data and data mining tools.

Skills: Bioinformatics, Java, web

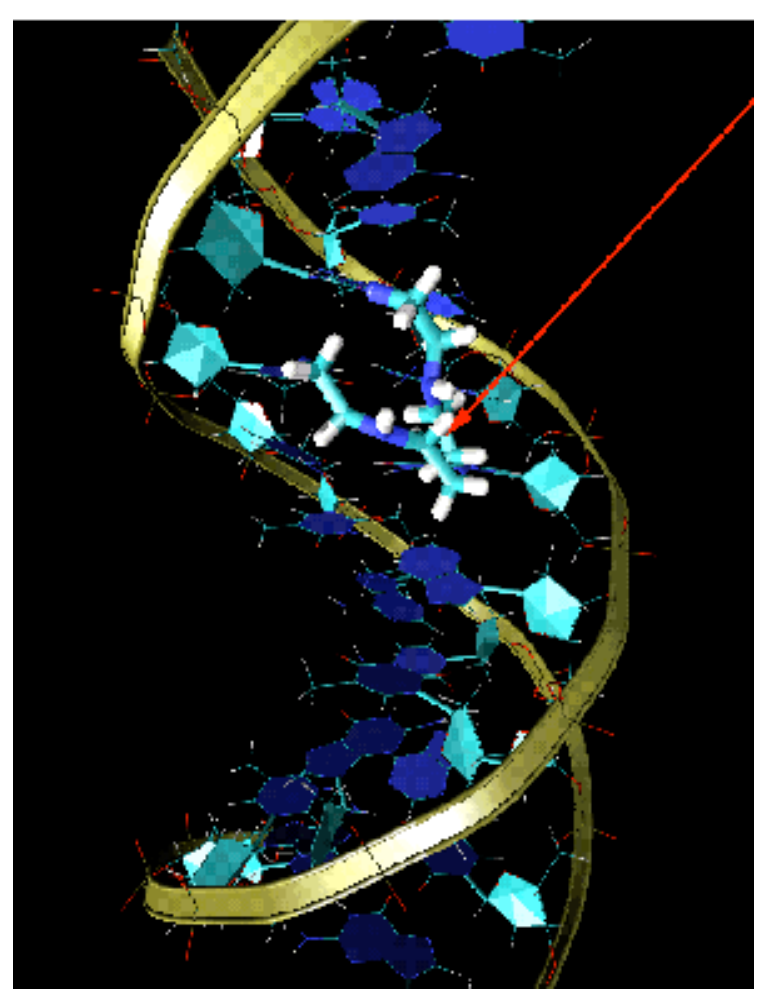
technology, some Perl and C 


\section{Biosciences - cont.}

Computer Scientists at LLNL were the first to develop software to identify pathogins. This work supports DHS bio-science and bio-security goals

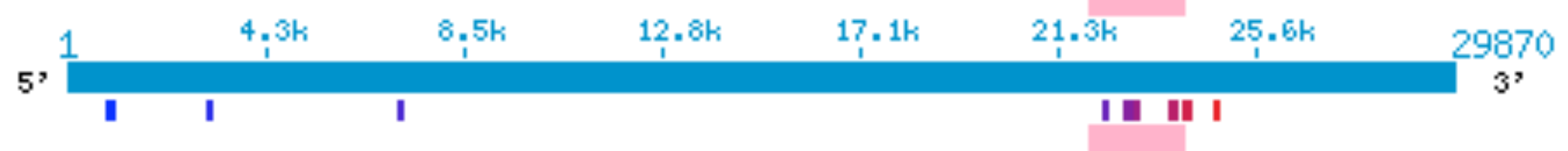

In 20 minutes, KPATH identified a unique region of the SARS genome, leading the way for human diagnostics

LLNL has earned a lead role within DHS for pathogen informatics

Chemical and Biological Nonproliferation Program

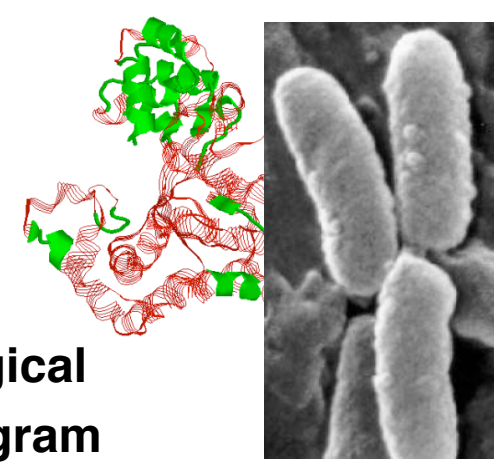




\section{Atmospheric and Climate Modeling}

LLNL develops codes to do climate, ocean and atmospheric modeling. The example to the right is a simulation

superimposed on a real picture of a tire fire in Tracy, CA.

The National Atmospheric Release Advisory Center uses this predictive capability to map the probable spread of hazardous materials released into the atmosphere such as during the Chernobyl disaster.

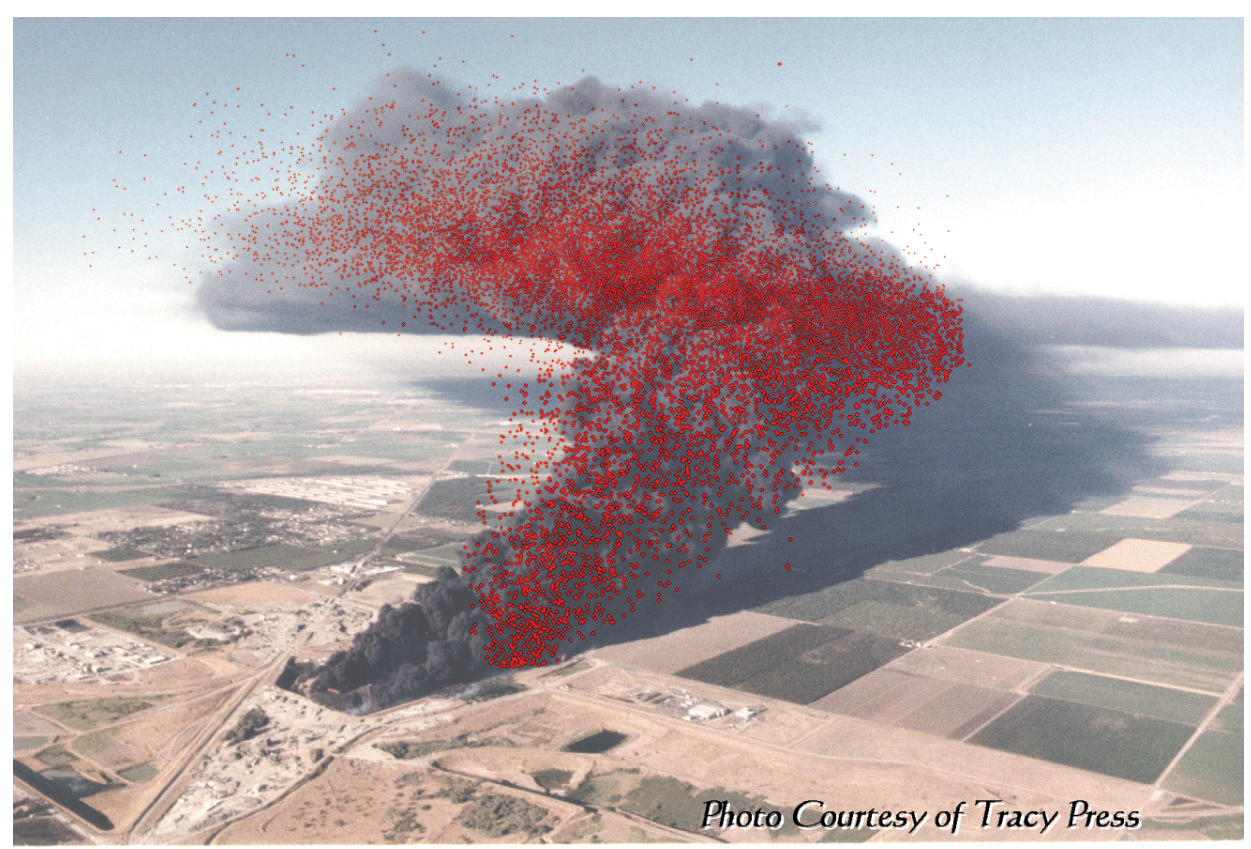

Computer Scientists work with other scientists to develop these atmospheric, ocean and climate modeling codes and supporting tools. 


\section{The National Ignition Facility (NIF)}

- NIF is a key component of the National Nuclear Security Administration's (NNSA's) Stockpile Stewardship Program, whose mission is to maintain the safety, reliability, and effectiveness of our nation's nuclear stockpile without underground nuclear testing.

- The primary mission of NIF is to attain fusion ignition in the laboratory. This will provide the basis for future decisions about fusion's potential as a long-term energy source.

- High-energy-density regimes accessible though NIF experiments will yield new insight into the origin of our universe. 


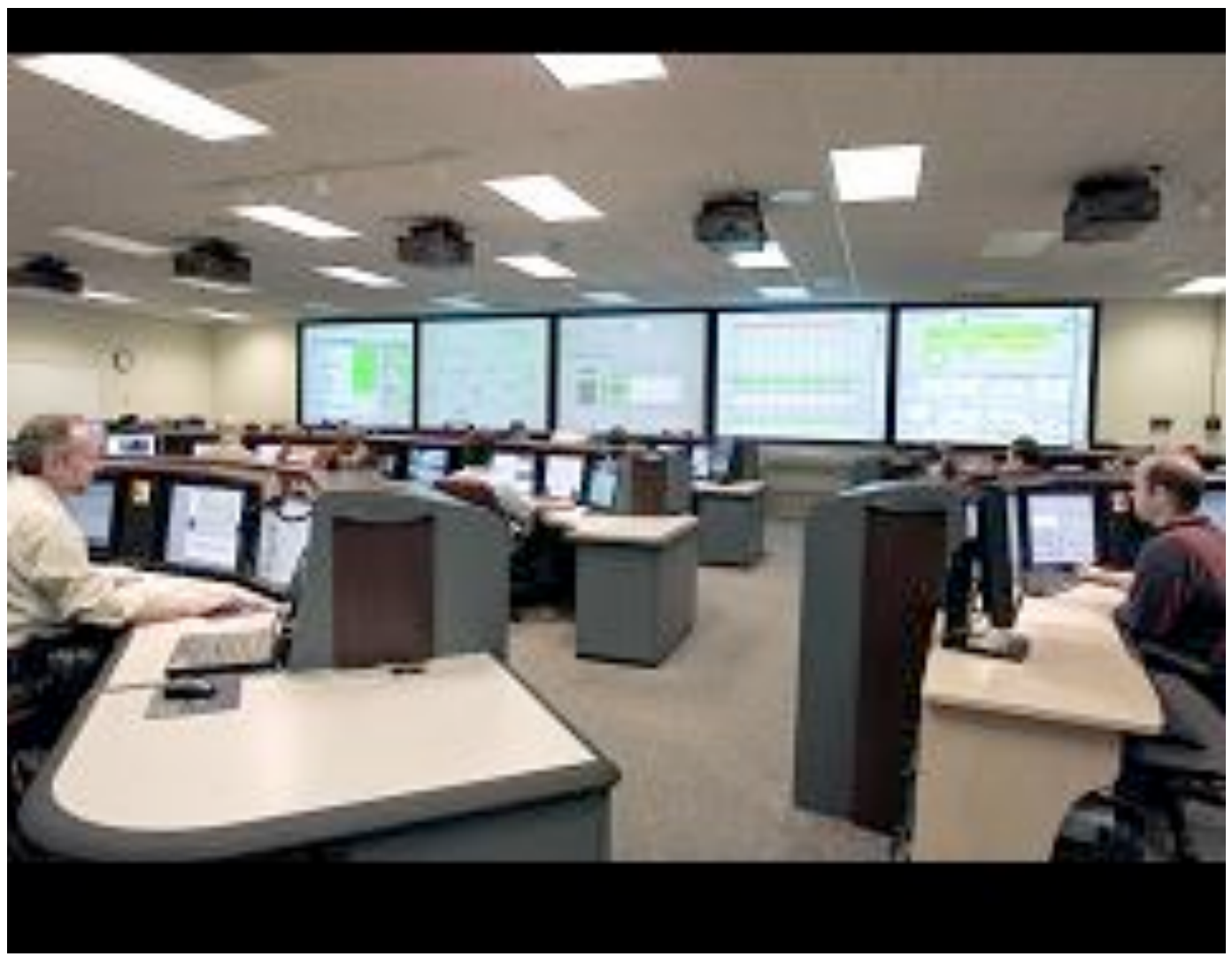

Computer Scientists team with Engineers to develop control system software such as shown to the left. They also develop database applications, and analysis software in support of NIF.

Skills: OO, embedded systems, Oracle, Java and user interface design 


\section{Stockpile Stewardship}

Stewardship of the U. S. nuclear stockpile is the foremost responsibility of the Lawrence Livermore National Laboratory. In the absence of nuclear testing, we now rely on interrelated computer calculations, validated by non-nuclear experimental results and benchmarked against past nuclear test data, for the continued certification of the stockpile.

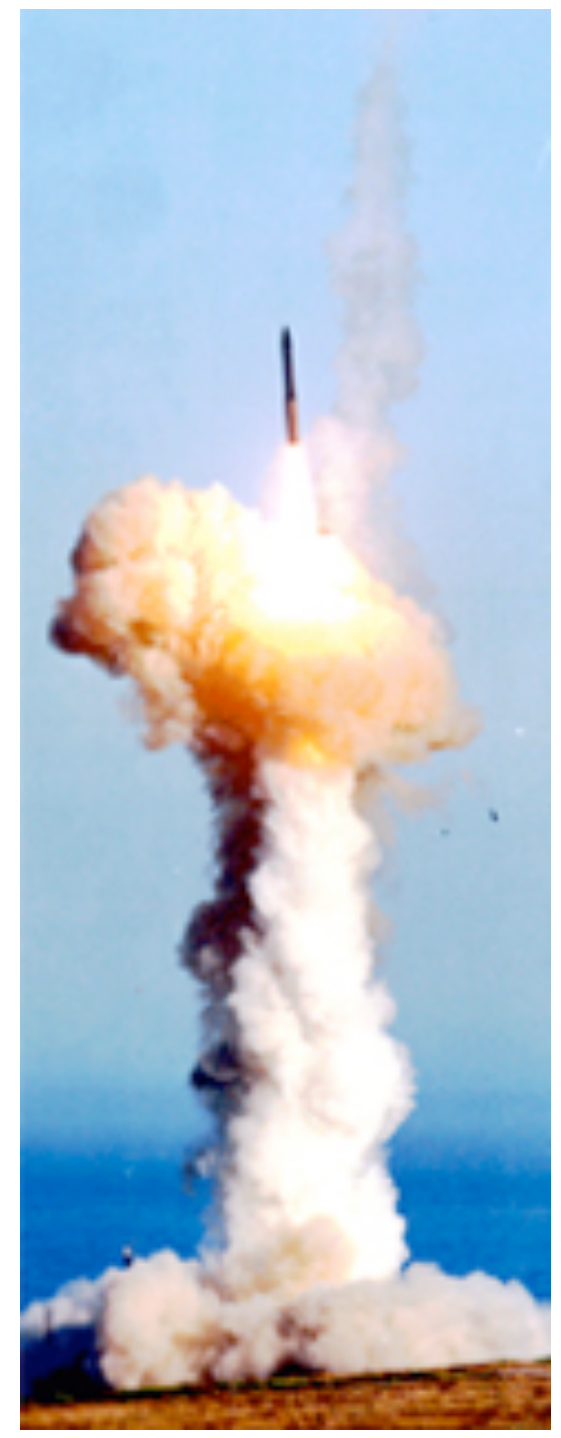




\section{Stockpile Stewardship - cont.}

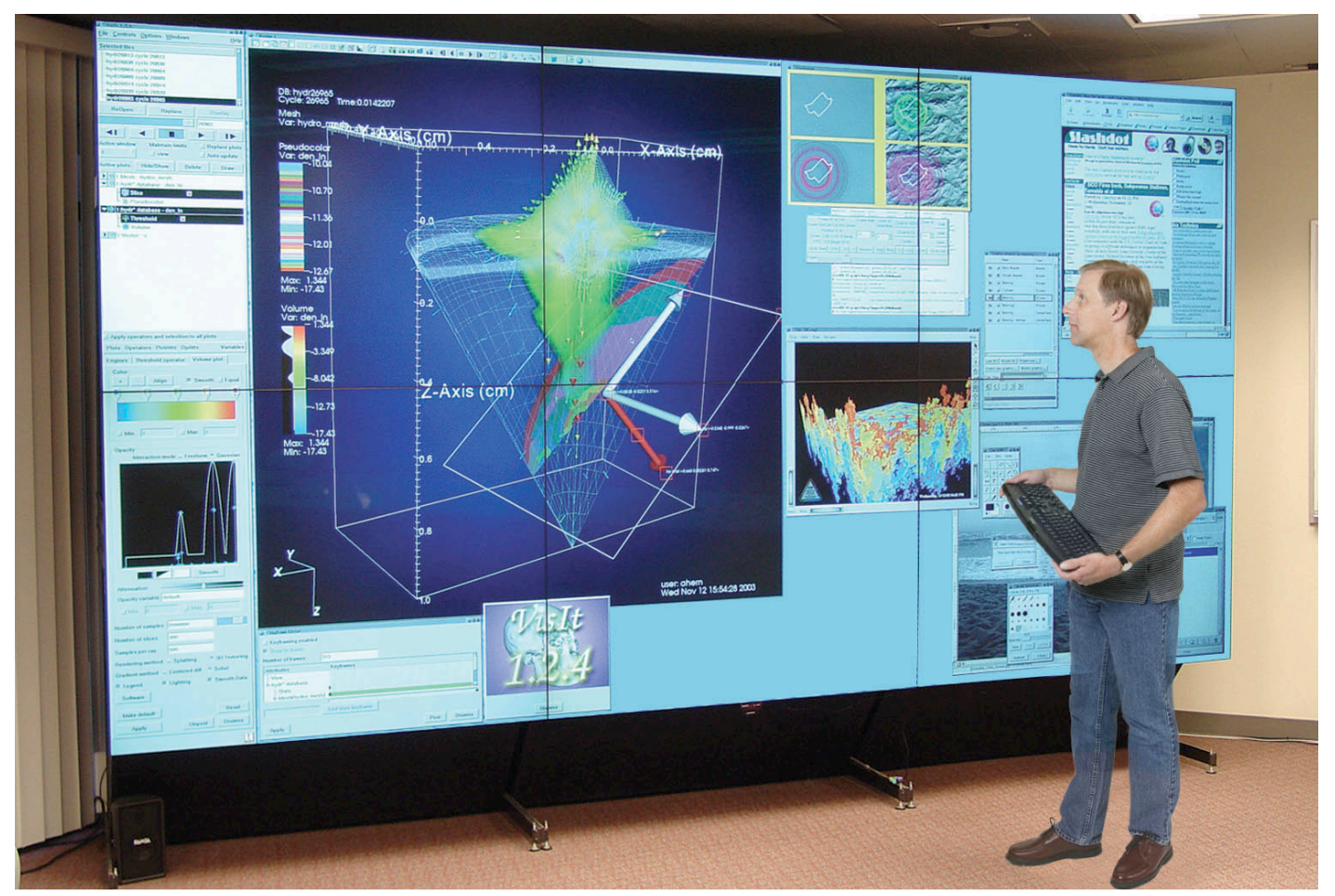

Eric is the Project Leader for the Vis It visualization code that is displaying the data to the left. In 2005, Eric and his team won an R\&D 100 Award.

Here Vislt is being used to show the density analysis of a National Ignition Facility test target under laser bombardment.

Computer Scientists work with Physicists to develop the simulation codes that support the Stockpile Stewardship program. They also develop the support tools such as the parallel visualization codes to display this data. 


\section{CASC
Con}

\section{CASC basic math research tackles difficult simulation science needs}

- Scalable linear solvers

- Fundamental algorithm research in optimal-complexity multigrid methods

- Massively parallel implementations

- PDEs in complex geometry

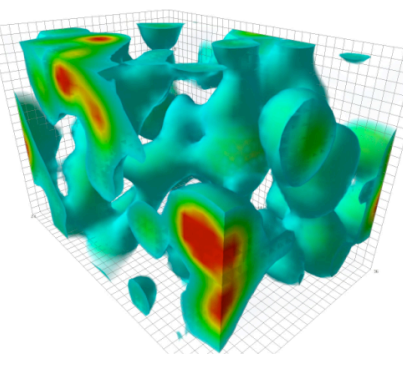

- Fundamental research in efficient meshing and discretization methods

- Multiscale Mathematics

- Improved kinetic algorithms for moderately collisional plasmas
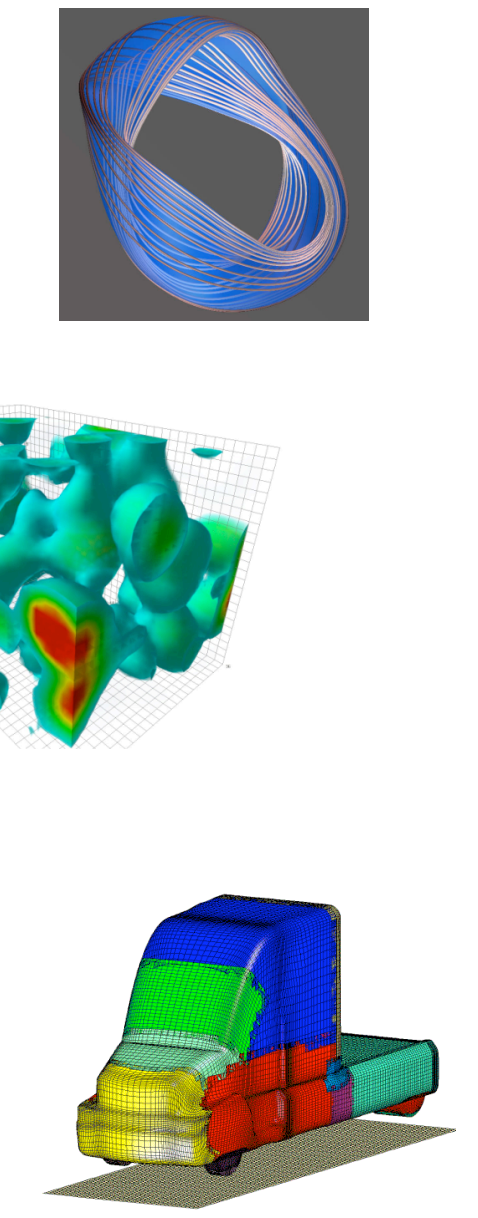


\section{Software Quality Assurance}

\section{LLNL Software Quality Assurance initiative}

- Institutionally-funded SQA program provides framework for quality and compliance

- Our Computer Scientists are a resource within LLNL and

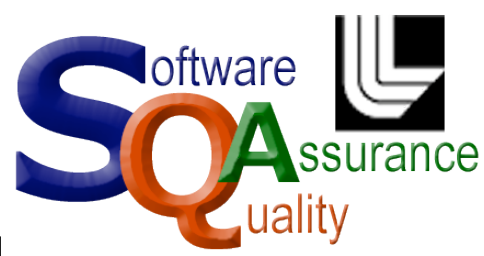
across DOE

- LLNL chairs DOE SQA Subcommittee

- LLNL Computer Scientists participate on DOE safety software assessments

- LLNL programs requesting SQA consulting and assessments

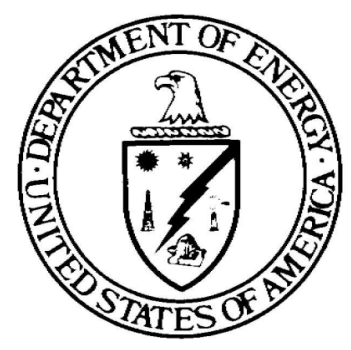




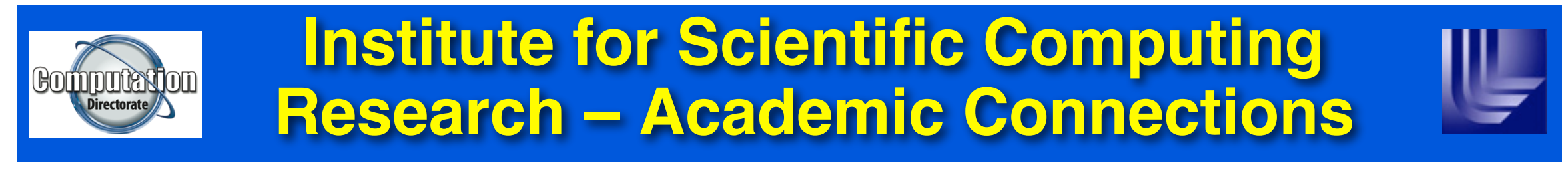

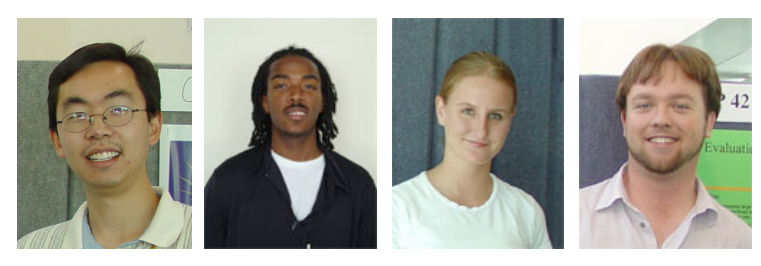

Summer Program

11 faculty
91 students and

Extensive interactions with UC

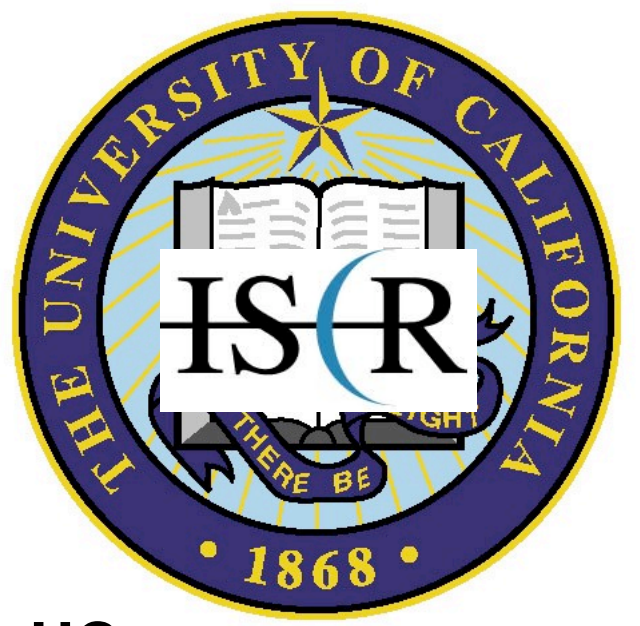

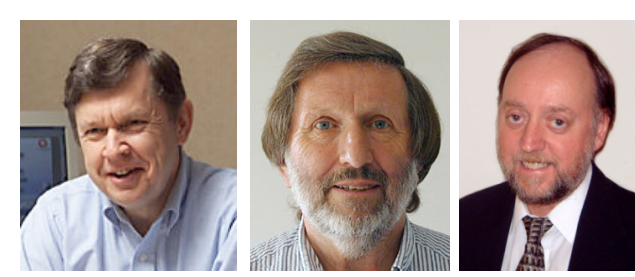

Seminars \& Visitors

252 visits and

84 seminars

Lasting Relationships Sabbatical visitors Students \& postdocs UCSD (data sciences)

UCD (visualization)

UCLA (IPAM affiliate)

PI-to-PI interactions at 9 campuses

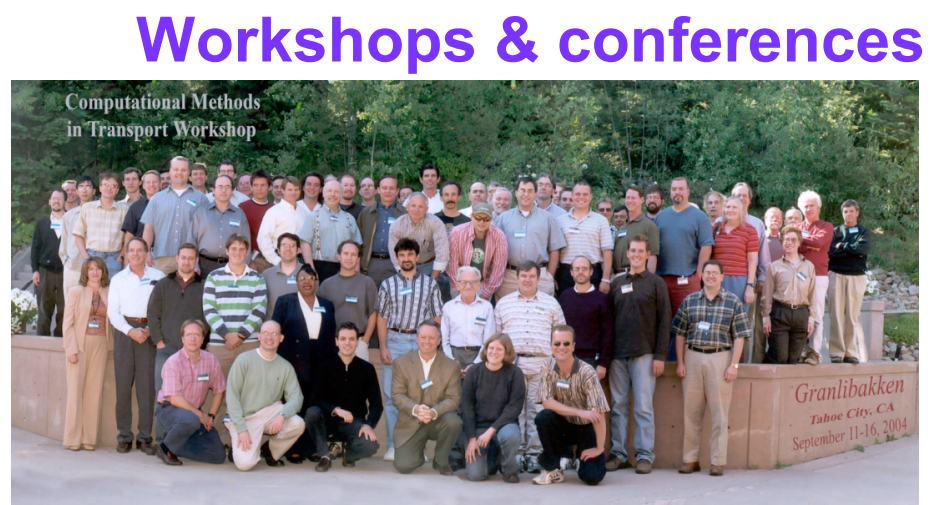




\section{Computer Scientists recognized for significant contributions}

Two R\&D 100 Awards

Eric Brugger, Sean Ahern, Kathleen Bonnell, Hank Childs, Linnea Cook, Jeremy Meredith, Mark Miller, Brad Whitlock, Vislt software

David Pletcher, Jim Schek, Adaptable Radiation Area Monitor

Sapphire Team earns three more patents

Chandrika Kamath and her team earned three more patents for their work in scientific data mining

\section{Featured publications}

Ivan Ovcharenko's article on Gene Deserts and Regulatory Elements is featured on cover of Genome Research

Michael Wickett contributes to climate studies deemed one of Top 100 science stories of 2005 by Discover Magazine

CAR scientists on 3 of 6 Gordon Bell Prize finalists

Erik Draeger, Bor Chan, Keith Henderson, Bronis de Supinski, Kim Yates, Andy Yoo
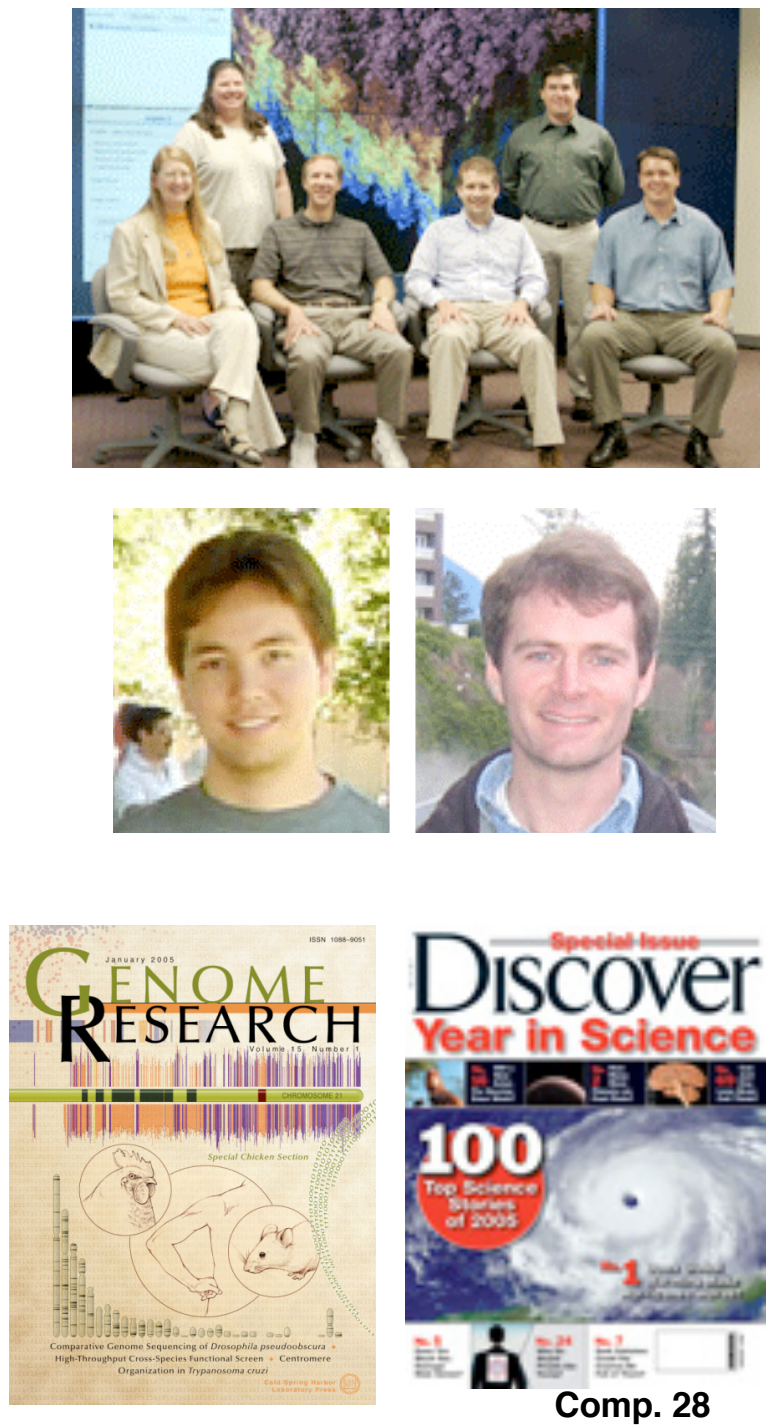


\section{Computer Scientists on three of six Gordon Bell Prize finalists}

\section{Gordon Bell Prize Winner}

100+ TFlop Solidification Simulations

- Fred Streitz (PAT), Kim Yates, Bronis de Supinski, Bor Chan with colleagues from IBM

Two other finalists

\section{Large-Scale FMPD Simulations}

- Francois Gygi, Erik Draeger, Bronis de Supinski, Kim Yates with colleagues from Carnegie-Mellon, Vienna University of Technology, and IBM Watson

\section{Scalable Breadth-First Search Algorithm}

- Andy Yoo, Keith Henderson with colleagues from Sandia, Ohio State, and D.E.Shaw

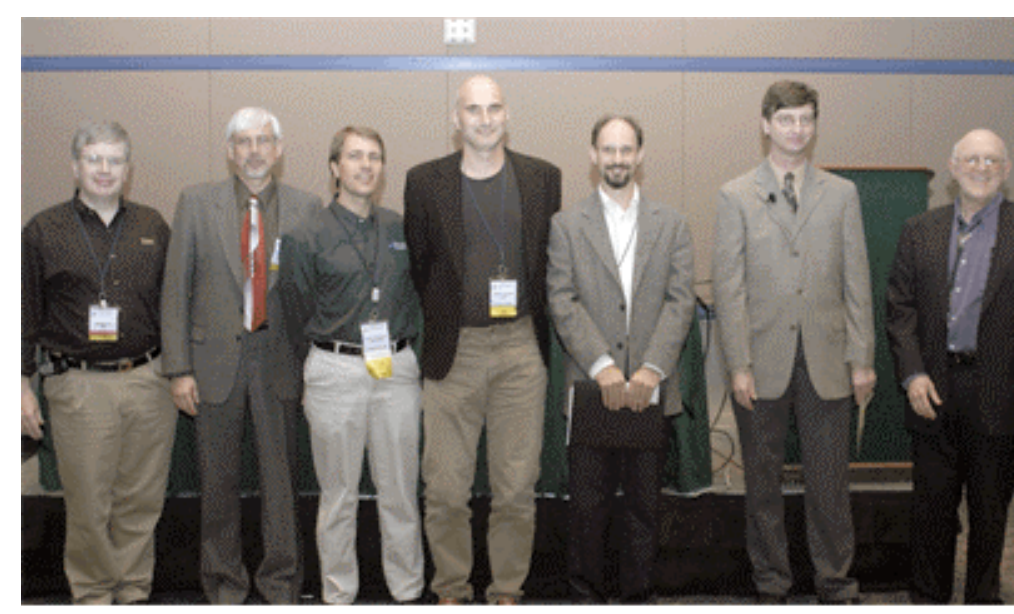

The Gordon Bell award-winning team (from left): James Sexton of IBM, Kim Yates, Bronis de Supinski, James Glosli, and Fred Streitz of LLNL, are pictured with Bill Gropp of Argonne, who chaired the prize committee, and C. Gordon Bell. Team members not pictured are Mehul Patel and Bor Chan from LLNL, and John Gunnels of IBM. 


\section{BlueGene/L and Purple are the \#1 and \#3} fastest computers in the world

- Blue Gene/L \#1 (280.6 teraflops on Linpack)

- Purple \#3 (63.39 teraflops on Linpack)
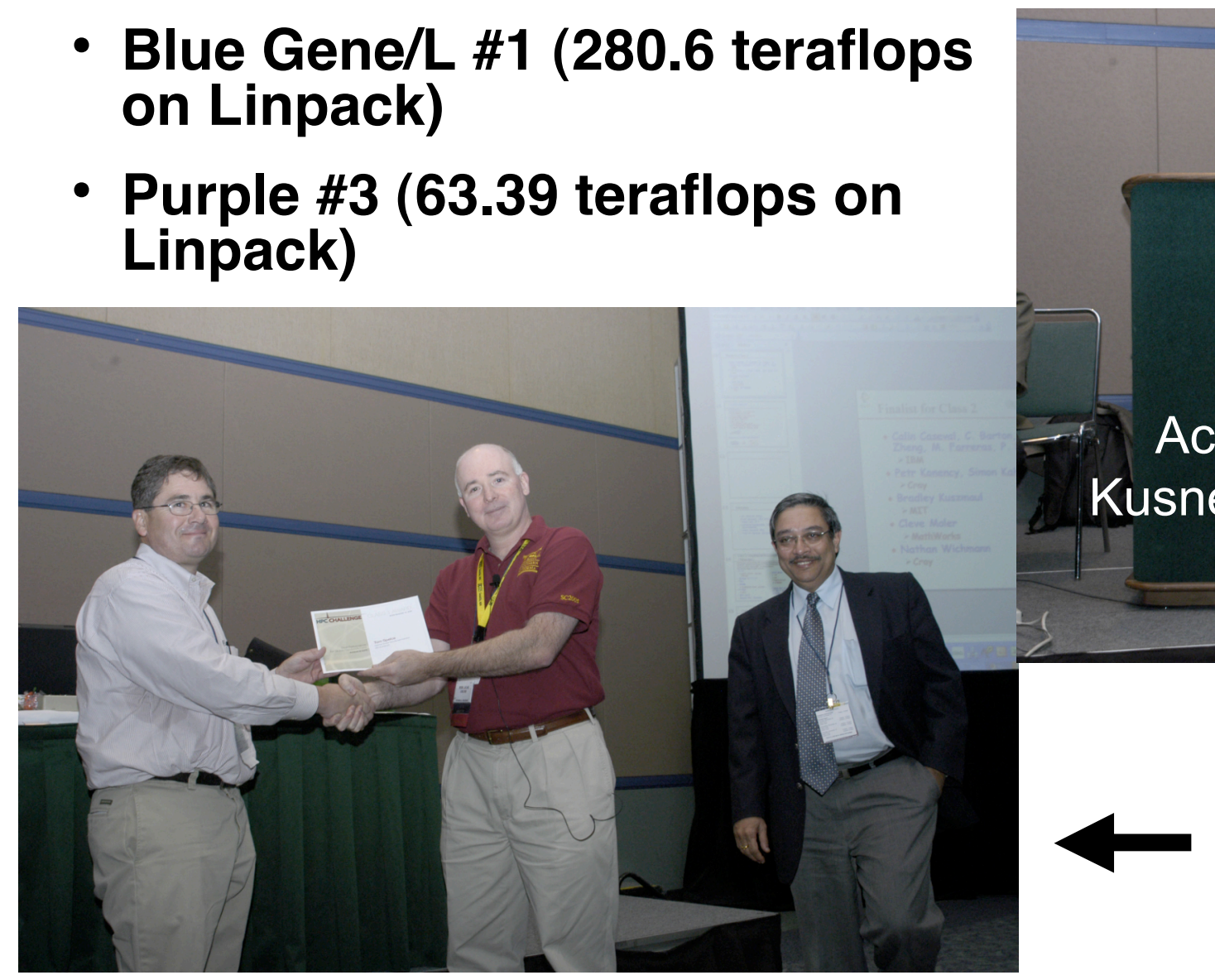

Accepting award Tom Spelce, LLNL and Dr. Tilak K. Agerwala, IBM T. J. Watson Research Center

\section{Blue Gene/L swept all four HPC Challenge Class 1 benchmark awards \\ 4}




\section{Continuing Education}

- LLNL has excellent continuing education benefits

- The Laboratory provides opportunities to eligible employees to pursue academic course work and degrees of interest to the mission of the Laboratory. Support may include fee reimbursement and/or time off with pay to attend classes.

- Several on-site university programs make learning even more convenient for employees. 


\section{Disclaimer and Auspices}

This document was prepared as an account of work sponsored by an agency of the United States Government. Neither the United States Government nor the University of California nor any of their employees, makes any warranty, express or implied, or assumes any legal liability or responsibility for the accuracy, completeness, or usefulness of any information, apparatus, product, or process disclosed, or represents that its use would not infringe privately owned rights. Reference herein to any specific commercial products, process, or service by trade name, trademark, manufacturer, or otherwise, does not necessarily constitute or imply its endorsement, recommendation, or favoring by the United States Government or the University of California. The views and opinions of authors expressed herein do not necessarily state or reflect those of the United States Government or the University of California, and shall not be used for advertising or product endorsement purposes.

This work was performed under the auspices of the U.S. Department of Energy by University of California Lawrence Livermore National Laboratory under contract No. W-7405-Eng-48.

\section{UCRL-PRES-}

